Karstenia 50: 35-44, 2010

\title{
Rare corticioid fungi in Finland - records of new and little collected species (Basidiomycota)
}

\author{
PANU KUNTTU, MATTI KULJU and HEIKKI KOTIRANTA
}

\begin{abstract}
KUNTTU, P., KULJU, M. \& KOTIRANTA, H. 2010: Rare corticioid fungi in Finland - records of new and little collected species (Basidiomycota). - Karstenia 50: 35-44. Helsinki. ISSN 0453-3402.

Peniophorella tsugae, Phlebiella alnicola and Trechispora araneosa are reported as new to Finland. New records of Hastodontia halonata, Helicogloea lagerheimii and Peniophorella echinocystis are presented and notes of the habitats and substrates are given. Descriptions of the new species and $H$. halonata are given as well as microscopical drawings. The taxonomy of $P$. alnicola is briefly discussed and comparison between Peniophorella pallida and $P$. tsugae is made. Most new Finnish records derive from SW Finland, from forested islands of the Archipelago Sea and mainland coastline. Inventories were carried out during late summer and autumn 2008 and 2009. Hastodontia halonata is reported as new to Estonia.
\end{abstract}

Keywords: Basidiomycetes, Finland, Archipelago Sea, corticioid fungi, taxonomy

Panu Kunttu, University of Eastern Finland, School of Forest Sciences, P.O. Box 111, FI-80101 Joensuu, Finland; e-mail: panu.kunttu@uef.fi

Matti Kulju, Ylispuuntie 13,FI-90420 Oulu,Finland; e-mail:m.kulju@kolumbus.fi

Heikki Kotiranta, Finnish Environment Institute, P.O. Box 140, FI-00251 Helsinki, Finland; e-mail: heikki.kotiranta@ymparisto.fi

\section{Introduction}

The knowledge of corticioid species in Finland is improving. The recent check-list of aphyllophoroid fungi (Kotiranta et al. 2009) gives a good basis. It lists altogether 980 aphyllophoroid species from Finland. A majority of these, 752 species, occur also or even solely on the coastal region of south-western Finland, including the Archipelago Sea (Kotiranta et al. 2009). After that check-list, one new corticioid species has been reported from Finland (Kunttu et al. 2009). According to the check-list, there are 422 corticioid species in Finland. No large scale biogeographical or ecological research concentrated on aphyllophoroid fungi has been carried out in the Archipelago Sea area, where most of the species reported here were collected. Some general publications, however, exist (e.g. Vauras 2000). The current knowledge of the species distribution and habitat requirements is still insufficient.
The Archipelago Sea is the most southwestern part of the Finnish coastline. This makes it biogeographically interesting. It belongs to the Hemiboreal zone (Ahti et al. 1968) and consists of thousands of islands ranging from small skerries to islands of several hundreds of hectares in size. Herb-rich forests are more common than on the continent. Larger islands have a long history of traditional land use by, e.g., grazing domestic animals. Some of the smaller islands have been saved from intensive exploitation of forests, and only firewood has been collected. Lindgren et al. (2001) list many highly valuable biotopes in the archipelago, including different types of forests. Field survey was carried out also in mainland, in the town of Kaarina, on the south-western coast. These forests are close to densely populated areas. The rare species in this paper were found during extensive ecological studies resulting in 
ca. 700 collections. The results of these studies will be published separately.

\section{Materials and methods}

Thirty spores per specimen were measured in Cotton Blue (CB). The other mounting media used were: Meltzer's reagent (MLZ) and 5\% potassium hydroxide $(\mathrm{KOH})$. The following abbreviations are used: $\mathrm{L}=$ spore length, $\mathrm{L}^{*}=$ mean spore length, $\mathrm{W}=$ spore width, $\mathrm{W}^{*}=$ mean spore width, $\mathrm{Q}=$ range of the variation in $\mathrm{L} / \mathrm{W}$-ratio, $\mathrm{Q}^{*}=$ quotient of the mean spore length and mean spore width (L/W). In the species descriptions spore measurements are based on mean values from each collection. The variation is given, with the mean value of all collections given in between. None of the measurements derives from a spore print. Measurements are summarized in Table 1.

Finnish national uniform grid system $\left(27^{\circ} \mathrm{E}\right)$ according to Heikinheimo \& Raatikainen (1981) was used for coordinates and biogeographic provinces according to Hansen $\&$ Knudsen (1997). Collections were made mainly from the hemiboreal zone in the biogeographic province of Varsinais-Suomi $(\mathrm{Ab} / \mathrm{V})$. Specimens are deposited in the herbarium of the University of Turku (TUR) and/or in the reference herbarium of Heikki Kotiranta (H.K.). The Finnish national red-listing evaluation of IUCN Red List Categories follows Rassi et al. (2001). The decay stage classification of trunks is according to Renvall (1995). Nomenclature of the genus Hyphodontia sensu lato follows Hjortstam \& Ryvarden (2009) and others mainly Kotiranta et al. (2009).

Panu Kunttu (PK) surveyed and collected the material between July and November in 2008, with support by Timo Kosonen, and from August to October in 2009. The senior author wrote the "Introduction" and a part of "Materials and methods". The specimens were identified and the measurements made by Matti Kulju (MK) and Heikki Kotiranta (HK); descriptions, drawings and taxonomical notes by HK. The paper was finished together.

\section{List of species}

Hastodontia halonata (J. Erikss. \& Hjortstam) Hjortstam \& Ryvarden - Fig. 1

Basidiocarp resupinate, first smooth, later partly tuberculate, relatively thick, but soft, when old heavily cracking, at first pale cream-coloured, later cream-coloured. Margin not differentiated, distinct. Hyphal system monomitic, all hyphae clamped, thick-walled, cyanophilous, partly slightly dextrinoid, $\mathrm{KOH}-$. Subicular and contextual hyphae 2-3 $\mu \mathrm{m}$ wide. Subhymenial hyphae richly branched, thin- to slightly thickwalled, 2.5-3 $\mu \mathrm{m}$ diam. Cystidia of two types: 1) capitate cystidia (apex 3.5-4 $\mu \mathrm{m}$ diam) very common, projecting, normally basally slightly widened, at first thin-walled, later bases with thickened walls, rarely with adventitious septa, $(28-) 32-44(-47) \times(3.5-) 4(-4.5) \mu \mathrm{m}$, and 2) gloeocystidia rare, or in some parts very common, mostly enclosed, at first tubular, later moniliform especially in apical part, rarely with slightly thickened walls and branched, (33-)45$90(-112) \times(3-) 4-5 \mu \mathrm{m}$. Basidia relatively small, basally clamped, with thickened walls, cylindrical, with one or two constrictions, (8-)11-15(17) $\times(3-) 3.5-4 \mu \mathrm{m}$, with four, very thin, up to $3 \mu \mathrm{m}$ long sterigmata. Spores cylindrical or subcylindrical, abaxial and ventral sides often straight, sometimes slightly convex, 4.4-4.8 $\times$ 2.1-2.2 $\mu \mathrm{m}, \mathrm{L}^{*}=4.6 \mu \mathrm{m}, \mathrm{W}^{*}=2.2 \mu \mathrm{m}, \mathrm{Q}=2-2.3$, $\mathrm{Q}^{*}=2.2$, with a very small apiculus, thin-walled, CB-, MLZ-, KOH-.

The Finnish records derive from very similar habitats and substrates: rocky, barren outcrops, with small, tough, old Pinus -kelo trees, which are decorticated and still very hard. In Sweden there are a few collections from the provinces of Småland and Uppland (holotype, see Eriksson \& Hjortstam 1969, p. 227). The three Norwegian collections from Akershus, Telemark and Vestfold are all from Pinus (Ryvarden et al. 2003). It has been found also from Russia, Caucasian area, Krasnodar region (Eriksson \& Ryvarden 1976). Two Swedish specimens grew on fallen fence of coniferous wood and one on Pinus (Eriksson \& Hjortstam 1969). The Caucasian specimen is from Pinus hamata branch (Langer 1994) and the Estonian from Juniperus communis. This is the first record from Estonia. Although $H$. halonata seems to be rare everywhere, it can hardly be threatened, due to the wide amplitude of biotopes, substrates and the ability to grow also on wood of small diameter.

Specimens examined: ESTONIA. Hiiu. Kõrgesaare, Kõpu Nat. Res, Kalaste, mixed old-growth forest, on corticated, hard (decay 1, diam $3.5 \mathrm{~cm}$ ) Juniperus communis with Xylodon crustosus, 58 $54^{\prime} \mathrm{N}, 2^{\circ} 07^{\prime} \mathrm{E}, 26 . \mathrm{IX} .2007$ HK 21959 \& Sell (H.K.). FINLAND. Varsinais-Suomi. Länsi-Turunmaa, Parainen, Kuggö, rocky and barren $P i$ nus-dominated old-growth forest, with old, but very short trees, on sawed, $3.6 \mathrm{~m}$ long, decorticated, hard (decay 1, diam $17 \mathrm{~cm}$ ) Pinus -kelo log, Grid 27 E 6680:(3)231, 25.X.2009 PK 5966 (TUR, H.K.). Parainen, Lielaxön, Bollböle, mixed forest on rocky outcrop, on decorticated branch of Pinus -kelo tree, Grid $27^{\circ}$ E 670089:(3)24784, 2.III.2000, Heinonen \& Heinonen 211-2000 (TUR, H.K.); 20.XI.2000 Heinonen \& Heinonen 1404-2000F (TUR, H.K.). 


\section{Helicogloea lagerheimii Pat.}

The three earlier records were made from different parts of the country from the three southernmost boreal zones: Hemiboreal, Southern Boreal and Middle Boreal zone. For a more detailed distribution and habitat data see Kotiranta et al. (2009). The new record is the southernmost and extends the list of the host tree species: Alnus glutinosa, Malus $\times$ domestica (cult.), Picea abies and now Sorbus aucuparia.

In Norway it has been found at least from Akershus and Nord-Trøndelag, in Sweden from the temperate zone to the boreal zone and in Denmark it is common. The main substrate is rotten deciduous wood (Torkelsen 1997). The current knowledge of the distribution is insufficient, and probably the species grows more widely in North Europe.

Specimen examined: FINLAND. Varsinais-Suomi. Kemiönsaari, Dragsfjärd, Vänö, on fallen Sorbus aucuparia (decay 3, diam $3 \mathrm{~cm}$ ), Grid $27^{\circ}$ E 6649:(3)230, 16.XI.2008 PK 4503 (TUR).

Peniophorella echinocystis (J. Erikss. \& A. Strid) K.H. Larss.

For the description and microscopical drawings see Eriksson \& Ryvarden (1975) and Kotiranta \& Saarenoksa (1993). According to the latter authors, the spores measure $8.2-8.7 \times 2.8-3.1$ $\mu \mathrm{m}, \mathrm{L}^{*}=8.5 \mu \mathrm{m}, \mathrm{W}^{*}=3 \mu \mathrm{m}, \mathrm{Q}^{*}=2.8$ (five collections). In this new collection ( $P K$ 3103) the spores are allantoid, (6.5-)6.7-9.5(-10.1) $\times$ (2.4-)2.7-3.1(-3.2) $\mu \mathrm{m}, \mathrm{L}^{*}=7.9 \mu \mathrm{m}, \mathrm{W}^{*}=2.9$ $\mu \mathrm{m}, \mathrm{Q}=2.4-3.2, \mathrm{Q}^{*}=2.7$, thus being slightly shorter and wider than in the other collections. Cystidia are clavate, $(29-) 36-61 \times 6-10 \mu \mathrm{m}$ as well as echinocysts, $24-28 \times 6-7 \mu \mathrm{m}$, or they are globose to subglobose, $7-13 \times 6-7 \mu \mathrm{m}$. Basidia clavate or subcylindrical, 16-21.5 x 5-6 $\mu \mathrm{m}$.

After the publication of Kotiranta et al. (2009), one more collection, besides that mentioned above, has been published from Southern Boreal zone (Etelä-Häme, Pälkäne; Halme 2010). All the Finnish collections derive from herb-rich forests, and the hosts are Betula sp., Populus tremula, Salix caprea and Sorbus aucuparia. P. echinocystis was classified as endangered (EN), but due to the new records and its ability to grow on many different kinds of deciduous trees, it will not be classified as threatened in the new evalu- ation of threatened species, which will be published in 2010 (HK, pers. comm.). Even though $P$. echinocystis has a hydnaceous hymenophore it is seldom collected. As the collection of Halme (2010) shows, it can grow also in Southern Boreal zone and the host does not necessarily be thick (e.g. Kotiranta \& Saarenoksa 1993). Our guess is that when more collectors are interested in corticioid species, more specimens will be found.

In Sweden it has been collected at least from Göteborg region and Uppland, from Temperate and Hemiboreal zones from deciduous wood (Vesterholt 1997). The habitats are similar to those in Finland (Eriksson \& Ryvarden 1975). In Sweden it is classified as Data Deficient (Gärdenfors 2010). P. echinocystis is widely distributed and has been reported at least from Denmark (Jülich 1984), Germany (Krieglsteiner 1991), Iran (Hallenberg 1978) and the United States (Ginns \& Lefebvre 1993).

Specimen examined: FINLAND. Varsinais-Suomi. Länsi-Turunmaa, Nauvo, Bodö, mesic herb-rich forest, on fallen, strongly decayed (decay 4, diam $46 \mathrm{~cm}$ ) Populus tremula trunk together with Phellinus tremulae and Rigidoporus corticola, Grid 27 E 6655:(3)207, 15.VII.2008, PK 3103 (TUR, H.K.).

Peniophorella tsugae (Burt) K.H. Larss. - Fig. 2

Basidiocarp resupinate, thin, in thickest parts somewhat hypochnoid, porose-reticulate under the lens $(\times 50)$, at the beginning white, later turning ochre, densely brown-spotted (lens $\times 50$ ). Old fruit bodies constrict and crack, and the thin, white subicular strands come visible. Margin not differentiated but distinct. Hyphal system monomitic, all hyphae clamped, CB-, MLZ-, KOH-. Subicular hyphae with thickened walls and low clamps, about $4.5 \mu \mathrm{m}$ wide. Contextual hyphae thin-walled, $3 \mu \mathrm{m}$ wide. Subhymenial hyphae thin-walled, richly branched (2-)2.5-3 $\mu \mathrm{m}$. Cystidia of two types: 1) projecting, subulate, very variable in size, but normally (30-)45-60 $\times(5-) 6-7.5(-9) \mu \mathrm{m}$, and 2) projecting or embedded, capitate and covered with brown resinous matter, $25-37 \times 5-8 \mu \mathrm{m}$. The apex is the widest part of the cystidium and the brown globule may be up to $27 \mu \mathrm{m}$ wide. Echinocysts slightly thickwalled, common on some areas on subicular hyphae, of various shape, and size, but normally basically ellipsoid, about $10 \mu \mathrm{m}$ long (excluding 
the spines), fairly often with bifurcate, unevenly dispersed, up to $3 \mu \mathrm{m}$ long spines. Basidia basally clamped, thin-walled, clavate, sometimes with internal repetition, $(21-) 24-31(-38) \times(5-)$ 7-8 $\mu \mathrm{m}$, with four up to $6 \mu \mathrm{m}$ long sterigmata. Spores ellipsoid - broadly ellipsoid - oblong ellipsoid - subcylindrical, 6.9-7.8 × 3.7-4.4 $\mu \mathrm{m}$, $\mathrm{L}^{*}=7.4 \mu \mathrm{m}, \mathrm{W}^{*}=4.1 \mu \mathrm{m}, \mathrm{Q}=1.8-1.9, \mathrm{Q}^{*}=1.9$, thin-walled, often glued in pairs-tetrads, CB-, MLZ-, KOH-.

We also studied Peniophorella pallida (Bres.) K.H. Larss. (Hyphoderma pallidum (Bres.) Donk) (Fig. 3) to find some other differences, except the shape of the spores, between it and $P$. tsugae. The basidiocarp of $P$. pallida is similar to that of $P$. tsugae, even if often thinner than in $P$. tsugae. The difference is, however, worthless for identification. Also the microscopical features are more or less identical. In P. pallida subicular hyphae run parallel to the substrate and are slightly thick-walled, (3-)4.5-5(-6) $\mu \mathrm{m}$ wide. Subhymenial hyphae are thin-walled, 2.5-3 $\mu \mathrm{m}$ diam. Two kind of cystidia are present: 1) subulate cystidia thin-walled, projecting up to $17 \mu \mathrm{m}$ above the basidia, normally (28-)40-60 $\times(6.5-) 7-8 \mu \mathrm{m}$, and 2) projecting or embedded, often capitate, sometimes mucronate, covered by resinous globule, $37-55 \times 7.5-9.5(-11) \mu \mathrm{m}$. Basidia are basally clamped, clavate, thin-walled, $(21-) 24-30(-36) \times(6-) 7-8 \mu \mathrm{m}$, with four up to $5 \mu \mathrm{m}$ long sterigmata. Echinocysts are subglobose or broadly ellipsoid, (9.5-)11-15 × 10.5-14 $\mu \mathrm{m}$ (incl. the up to $3 \mu \mathrm{m}$ long, sometimes bifurcate spines), $(8-) 9.2-11 \times(7.8-) 8.5-9 \mu \mathrm{m}$ (excl. the spines). Spores are allantoid - cylindrical, slightly bent, ventral side always concave, sometimes gently sigmoid, often glued in pairs - tetrads, 8.2-9.7 × 3.1-3.9 $\mu \mathrm{m}, \mathrm{L}^{*}=9 \mu \mathrm{m}, \mathrm{W}^{*}=3.4$ $\mu \mathrm{m}, \quad \mathrm{Q}=2.4-3.1, \mathrm{Q}^{*}=2.7$, thin-walled, $\mathrm{CB}-$, MLZ-, KOH-.

Burt (1926) did not mention the echinocysts in his description of P. tsugae (Corticium tsugae), nor Eriksson \& Ryvarden (1975), Jülich \& Stalpers (1980) or de Vries (1987) when he came to the conclusion, that $P$. tsugae is conspecific with $P$. pallida. Larsson (2007), however, showed that these two taxa are separate, and belong to the genus Peniophorella P. Karst. together with e.g., P. echinocystis. The only difference we could find between these two taxa was the shape of the spores: ellipsoid in P. tsugae $\left(\mathrm{Q}^{*}=1.9\right)$ and allantoid - cylindrical in $P$. pallida
$\left(\mathrm{Q}^{*}=2.7\right)$. However, the material of $P$. pallida seems not to be homogenous. The specimens collected from Juniperus (HK 5117, 22014) have wider spores $(\mathrm{W}=3.4-3.9 \mu \mathrm{m}, \mathrm{Q}=2.4-2.5)$ than those collected from Pinus $(\mathrm{W}=3.1-3.2 \mu \mathrm{m}$, $\mathrm{Q}=2.7-3.1)$. The specimen $H K 22014$ has often mucronate cystidia which are either naked and with brown contents or covered with brown resinous, amorphous matter. On the other hand, the length of the spores does not follow the host, i.e., both pine- and juniper dwelling specimens have short and long spores. If more than one species is involved, DNA analyses are needed and more material should be studied. Both, P. pallida and $P$. tsugae have echinocysts which in extreme cases resemble the spores of some tomentelloid species with their bifurcate, long spines.

The species is new to Finland. Peniophorella tsugae has been reported e.g., from Sør-Trøndelag in Norway (Ryvarden et al. 2003) and Gotska Sandön in Sweden (Eriksson \& Ryvarden 1975). The substrate in Norway was Pinus and in Sweden an unidentified stump in pine forest.

Specimens of $P$. tsugae examined: CANADA. Ontario. Norfolk county, Delhi N, on decorticated Thuja occidentalis, 25.V.1939 Cain (ex Herb. Cain UT 15220 in GB). FINLAND. Varsinais-Suomi. Kemiönsaari, Dragsfjärd, Vänö, 3.3 m long broken, much decayed (decay 4, diam $24 \mathrm{~cm})$, moss-covered trunk of Alnus glutinosa, Grid $27^{\circ}$ E 6649:3230, 14.XI.2008 PK 4494 (TUR, H.K.).

Specimens of P. pallida examined: ESTONIA. Hiiu. Kãina, Nasva, mixed grass-herb forest, decorticated $J u$ niperus communis (decay 3, diam $4 \mathrm{~cm}$ ), together with Vesiculomyces citrinus, 58 $48^{\prime} \mathrm{N}, 2^{\circ} 45^{\prime} \mathrm{E}, 27 . \mathrm{IX} .2007$ HK 22014 \& Sell (H.K.). FINLAND. Uusimaa. Inkoo, Sommarn Nat. Res., almost treeless island, strongly decayed pine timber (collapsed house), Grid $27^{\circ} \mathrm{E}$ 6648:(3)346, 25.V.1989, HK 7326 (H.K). Sipoo, PohjoisPaippinen, Rörstrand Nat. Res., Picea abies-dominated old-growth forest, on strongly decayed Juniperus, Grid 27ํㅡ 6706:(3)402, 9.X.1983 HK 5117 (H.K.). EteläHäme. Ruovesi, Siikakangas, dry Pinus sylvestris -dominated heath forest, on strongly decayed pine, Grid $27^{\circ} \mathrm{E}$ 6863:(3)352, HK 7384 (H.K.).

Phlebiella alnicola (Bourdot \& Galzin) Bondartsev \& Singer - Fig. 4

Basidiocarp resupinate, fairly thick, relatively tough, tuberculate or grandinoid, ochraceous or pale reddish, when cracking white subiculum visible (lens $\times 50$ ), margin arachnoid, distinct or pulverulent in areas where the conidia are born. Hyphal system monomitic, all hyphae 
clamped, CB-, MLZ-, KOH-. Subicular hyphae thin-walled, richly branched, $(1.5-) 2(-2.5) \mu \mathrm{m}$, intermixed with a few wider hyphae, up to $5 \mu \mathrm{m}$ diam. Tramal hyphae very thin-walled, 1.5-2.5 $\mu \mathrm{m}$ wide, difficult to discern, partly covered with rod-like crystals. Subhymenial hyphae very thinwalled, $2 \mu \mathrm{m}$ diam, covered with crystals which obscure the bases of basidia in $\mathrm{CB}$, but not in MLZ or KOH. Cystidia none. Basidia basally clamped, cylindrical, very thin-walled, pleural, (13-) 15-22(-25) × 4.5-5.5 $\mu \mathrm{m}$, with four up to 5 $\mu \mathrm{m}$ long sterigmata. Spores ellipsoid or broadly ellipsoid, ventral side often straight or concave, 3.3-4.1 $\times 2.6-3.3 \mu \mathrm{m}$, verrucose, with up to 0.2 $\mu \mathrm{m}$ long warts, but normally shorter, $\mathrm{CB}+(\mathrm{ex}-$ cept the warts), MLZ-, KOH-. Aleuroconidia ellipsoid - oblong-ellipsoid, often somewhat truncate, thick-walled (wall up to $1 \mu \mathrm{m}$ thick), 5-6.8 $\times$ 3.6-4.6 $\mu \mathrm{m}, \mathrm{CB}+$ (distinctly), MLZ-, KOH-. No conidiophores with attached aleuroconidia seen.

The nature of the basidia is easily seen in $\mathrm{KOH}$, while in $\mathrm{CB}$ they look very often terminal, when the bases are not visible; the hyphae are best seen in MLZ. We saw a few ampullaceous septa in subicular hyphae, but most clamps are low, typical for the genus Phlebiella. Bourdot \& Galzin (1928) compared P. alnicola with P. tulasnelloidea (Höhn. \& Litsch.) Ginns \& M.N.L. Lefebre, but in most books and check-lists $P$. alnicola is treated under Trechispora (e.g. Jülich \& Stalpers, 1980, Hjortstam et al. 1988, Hansen \& Knudsen 1997, Ryvarden et al. 2003, GhobadNejhad et al. 2009). But even if it shares characteristics common with Trechispora (tuberculate hymenophore, some ampullaceous clamps), we prefer Phlebiella due to the clearly pleural basidia. In our specimen the spore form slightly differs from that drawn by Eriksson (Hjortstam et al. 1988, p. 1492) in having ventral side straight or concave. Such spores are characteristic for Trechispora caucasica (Parmasto) Liberta, a species also with conidia. The conidia, however, are quite different, like the hyphae and basidia (Parmasto 1965 p. 226, Larsson 1995 p. 105, 106).

The species is new to Finland. Phlebiella alnicola is widely distributed (Jülich \& Stalpers 1980) but rare in the Nordic Countries, more common in Central- and South Europe and Caucasus (Hjortstam et al. 1988, Ghobad-Nejhad et al. 2009). It grows both on coniferous and deciduous wood (e.g. Hjortstam et al. 1988).
Specimen examined: FINLAND. Varsinais-Suomi. Kaarina, Ala-Lemu, Alnus glutinosa -dominated, seasonally flooded herb-rich forest close to the sea shore, on fallen branch (decay 3, diam $14 \mathrm{~cm}$ ) of A. glutinosa, Grid 27ํ E 6706:(3)241, 19.XI.2009 PK 5956 (TUR, H.K.).

Trechispora araneosa (Höhn. \& Litsch.) K.H. Larss. - Fig. 5

Basidiocarp resupinate, thin, granular, porose (lens $\times 50$ ), soft, white, margin not differentiated, distinct or with white rhizomorphs. Hyphal system monomitic, all hyphae with clamps. Hyphae in cords $2-4(-5) \mu \mathrm{m}$ wide, ampullate septa up to $8 \mu \mathrm{m}$ diam, encrusted. Widest tramal hyphae, which give rise to the hyphae projecting in apical apices, 5-6 $\mu \mathrm{m}$ wide, encrusted. Cystidia none. Basidia basally clamped, mostly terminal, seldom pedunculate, $10-15(-17) \times 5-6 \mu \mathrm{m}$, with four sterigmata. Spores ellipsoid, aculeate, $5.1 \times$ $4.1 \mu \mathrm{m}$ (incl. up to $0.8 \mu \mathrm{m}$ long aculei), $4.4 \times 3.1$ $\mu \mathrm{m}$ (excl. aculei). For a more detailed description see Larsson (1995).

The species is new to Finland. Trechispora araneosa belongs to the $T$. farinacea group, but is readily distinguished from the other species in the group by the wide, long-celled apical hyphae, which often bear characteristically shaped, "butterfly or bow-tie" -type crystals (Larsson 1995), and also by spores with long aculei and by lack of conidia. For the distribution and habitats, see Larsson (1995).

Specimen examined: FINLAND. Varsinais-Suomi. Kemiönsari, Dragsfjärd, Vänö, on broken, fallen $1.2 \mathrm{~m}$ long, strongly decayed Alnus glutinosa trunk (decay 5, diam $24 \mathrm{~cm}$ ) together with Trechispora hymenocystis and Vesiculomyces citrinus, Grid 27 E 6649:(3)230, 14.XI.2008 PK 4454 (TUR, H.K).

Acknowledgements: Societas pro Fauna et Flora Fennica and Ella and Georg Ehrnrooth Foundation are gratefully thanked for financial support to PK to carry out the surveys. Author PK's compliments go to MSc Timo Kosonen (University of Turku) and Sanna-Mari Rivasto (Dragsfjärd) who assisted during the fieldwork. We also want to thank Maija-Liisa and Pekka Heinonen (Parainen), for giving their specimens of Hastodontia halonata at our disposal. 
1.1

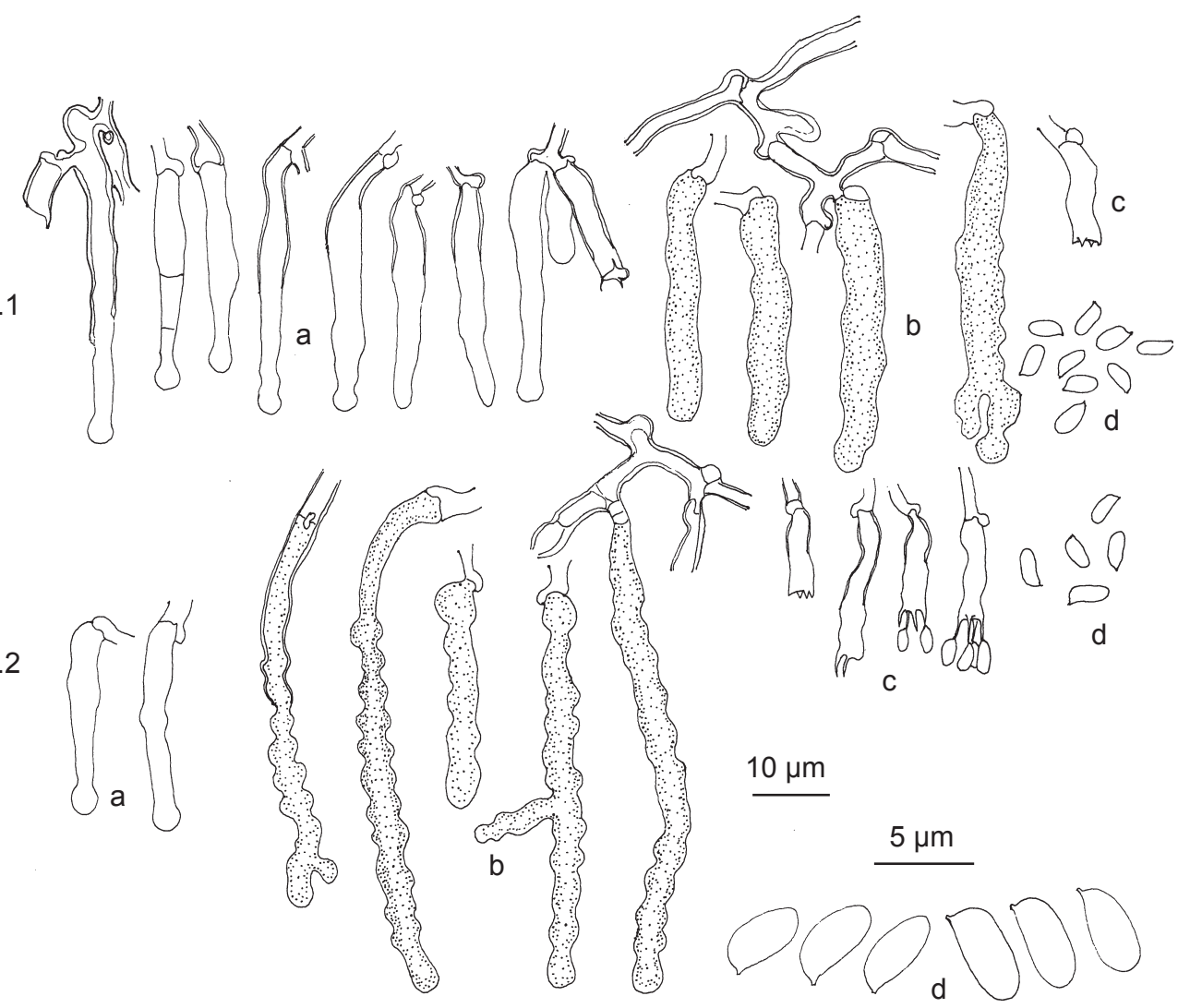

1.2

2.1

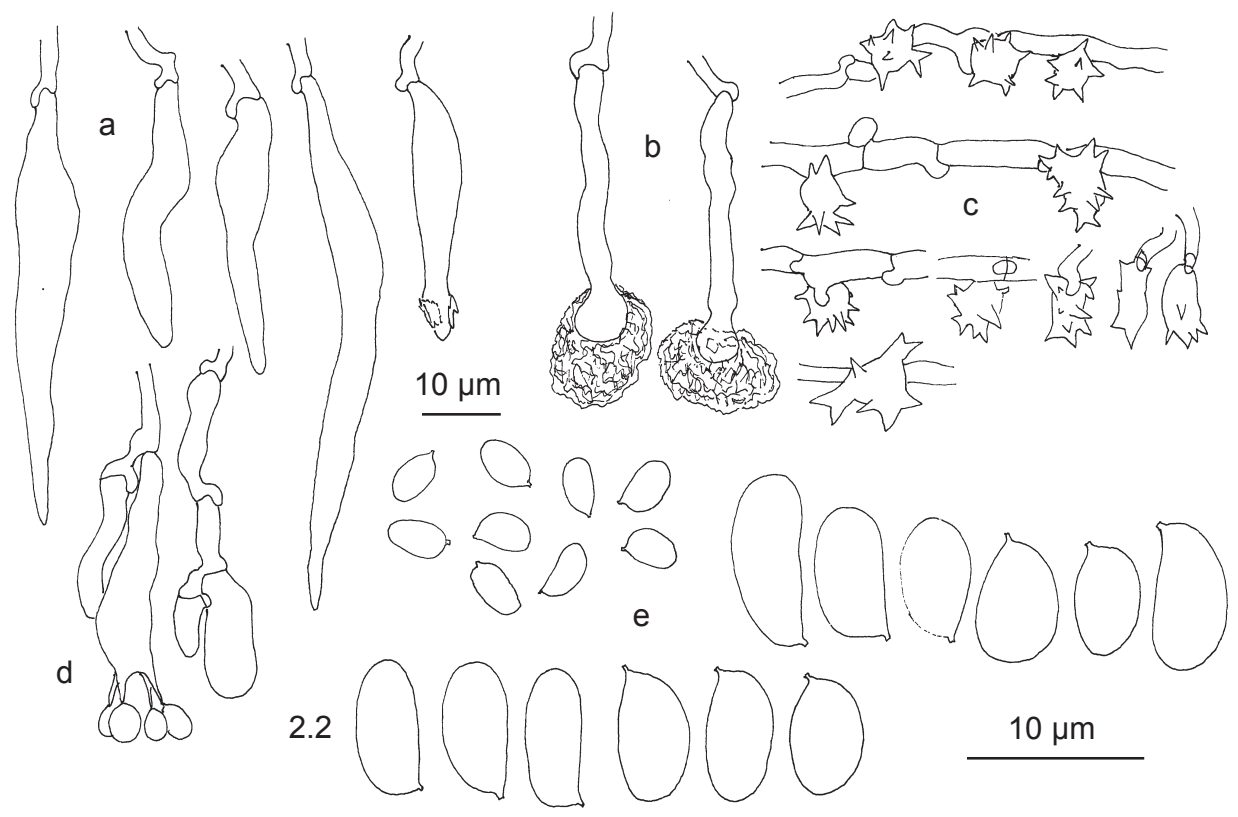


3.1
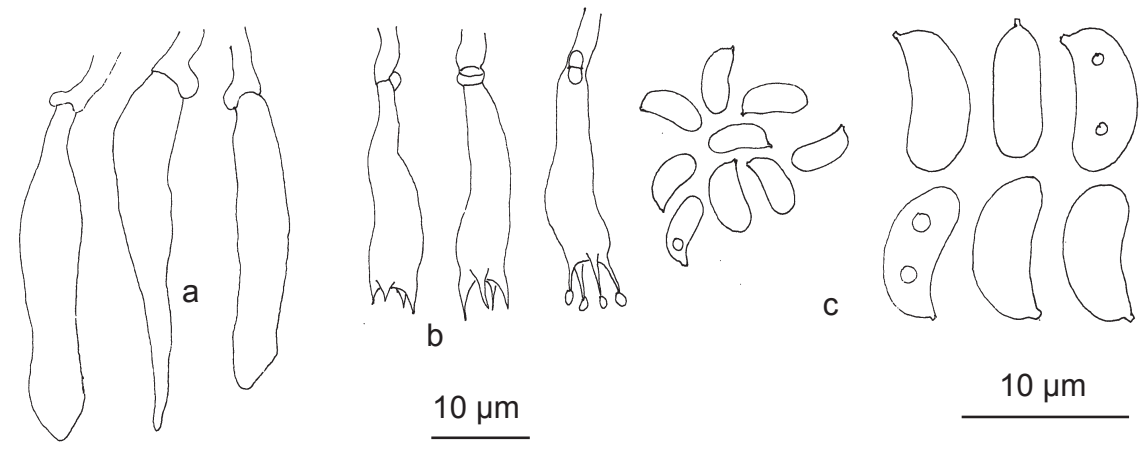

b

$10 \mu \mathrm{m}$

$10 \mu \mathrm{m}$

3.2
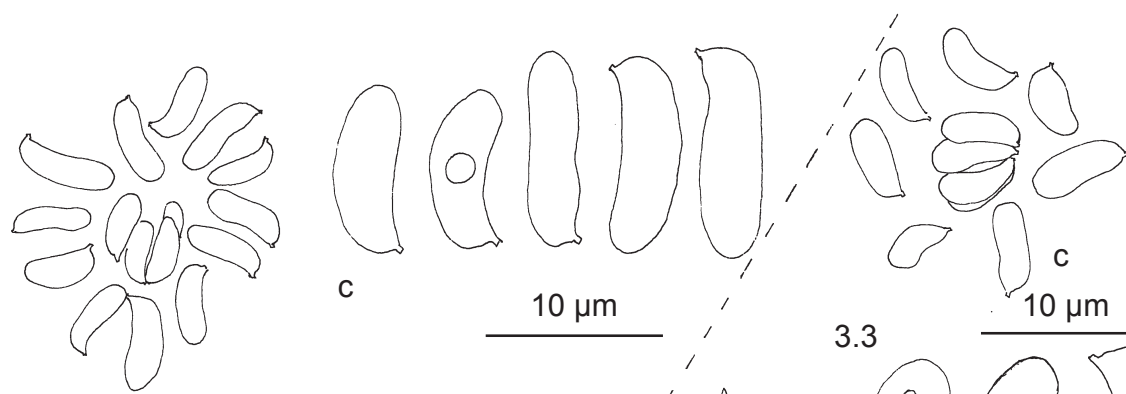

C
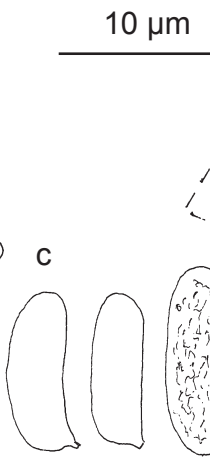

,

3.3

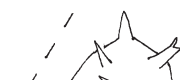

$10 \mu \mathrm{m}$

3.4
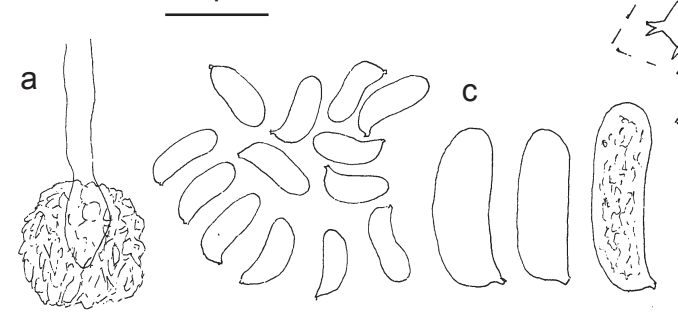

Kn
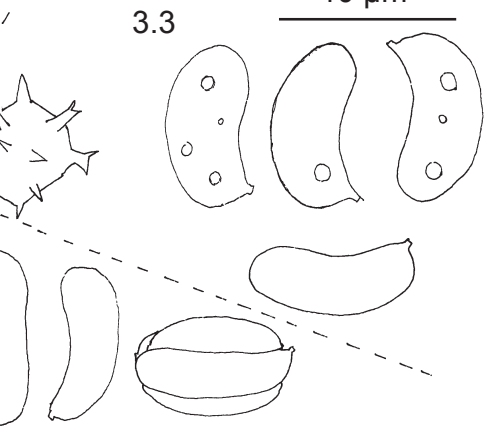

$$
10 \mu \mathrm{m}
$$

Fig. 3. Peniophorella pallida. 1) HK 22014 \& Sell, 2) HK 7326, 3) HK 5117, 4) HK 7384. - a = subulate- and mucronate cystidia, $\mathrm{b}=$ basidia, $\mathrm{c}=$ spores.

Fig. (Left above) 1. Hastodontia halonata. 1) Heinonen \& Heinonen 140-2000F, 2) HK $21959 \&$ Sell. $-\mathrm{a}=$ capitate cystidia, $\mathrm{b}=$ gloeocystidia, $\mathrm{c}=$ basidia, $\mathrm{d}=$ spores.

Fig. (Left under) 2. Peniophorella tsugae. 1) $P K 4494 a$, 2) Cain. $-\mathrm{a}=$ subulate cystidia, $\mathrm{b}=$ capitate cystidia, $\mathrm{c}=$ echinocysts on subicular hyphae, $\mathrm{d}=$ basidia, $\mathrm{e}=$ spores. 


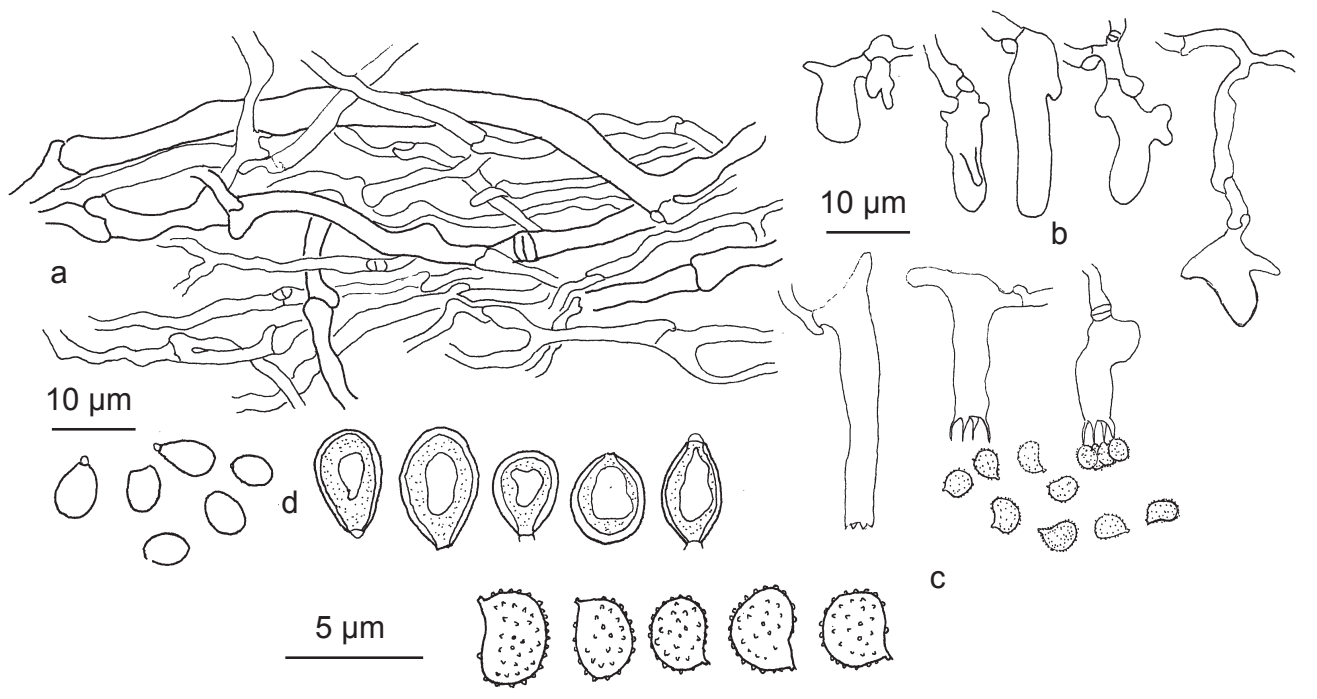

Fig. 4. Phlebiella alnicola, $P K 5956 .-\mathrm{a}=$ subicular hyphae, $\mathrm{b}=$ basidia at different stages of development, $\mathrm{c}=$ spores, $\mathrm{d}=$ aleuroconidia.

a
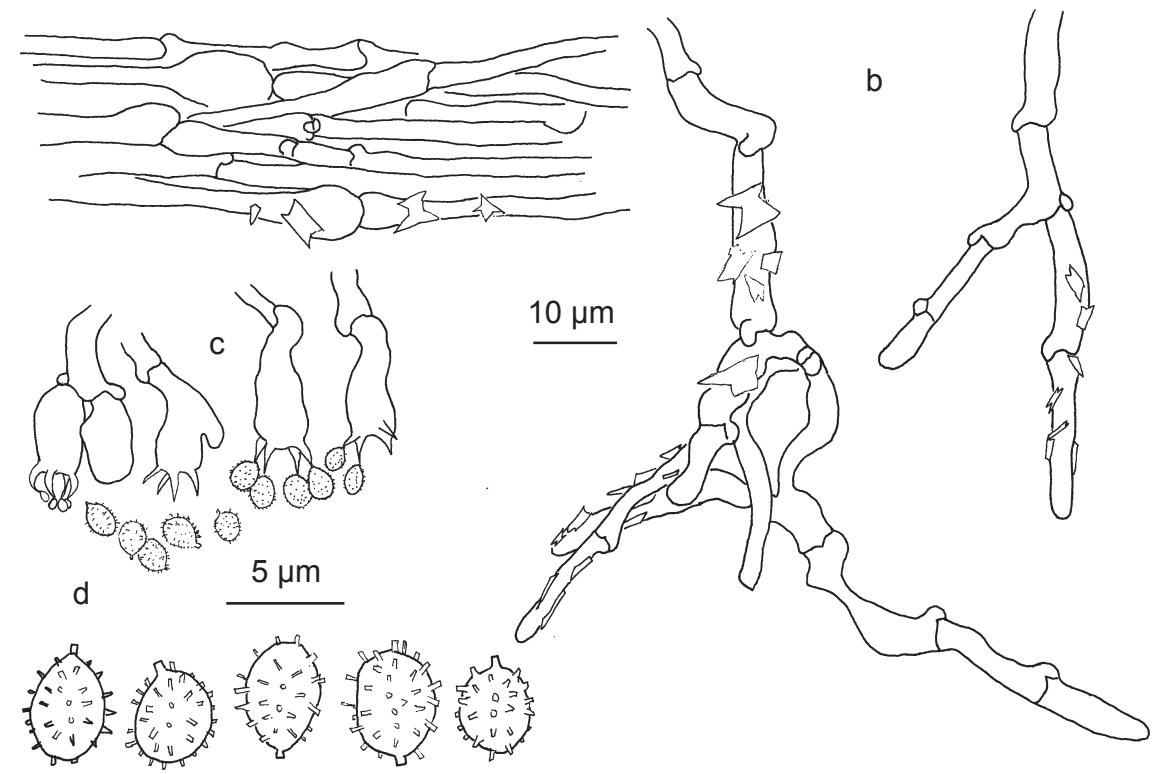

Fig. 5. Trechispora araneos $a, P K 4454 .-\mathrm{a}=$ subicular hyphae with crystals, $\mathrm{b}=$ wide, partly encrusted hyphae in apical apices, $\mathrm{c}=$ basidia at different stages of development, $\mathrm{d}=$ spores. 
Table 1. Spore and conidia dimensions of the studied specimens. The values set in boldface include at least $90 \%$ of the spores.

\begin{tabular}{|c|c|c|c|c|c|c|}
\hline H. halonata & $\mathrm{L}(\mu \mathrm{m})$ & $\mathrm{L}^{*}(\mu \mathrm{m})$ & $\mathrm{W}(\mu \mathrm{m})$ & $\mathrm{W}^{*}(\mu \mathrm{m})$ & Q & $\mathrm{Q}^{*}$ \\
\hline HK 21959 \& Sell & $4.2-5$ & 4.6 & $2-2.2$ & 2.1 & $2.0-2.5$ & 2.3 \\
\hline PK 5966 & $4-4.9(-5)$ & 4.4 & $\mathbf{2 - 2 . 3}(-2.8)$ & 2.2 & $1.8-2.3$ & 2 \\
\hline Heinonen 1404 & $(4.2-) 4.5-5.1(-5.5)$ & 4.8 & $\mathbf{2 - 2 . 5 ( - 2 . 6 )}$ & 2.2 & $1.8-2.6$ & 2.2 \\
\hline \multicolumn{7}{|l|}{ P. pallida } \\
\hline HK 22014 \& Sell & $7.6-8.9(-9.8)$ & 8.2 & $3.2-3.6(-3.8)$ & 3.4 & $2.2-2.7$ & 2.4 \\
\hline HK 7326 & 8.6-11.1 $(-11.5)$ & 9.7 & $2.7-3.4(-3.8)$ & 3.1 & $2.3-3.8$ & 3.1 \\
\hline HK 5117 & $(8.6-) 9-10.3(-11.7)$ & 9.7 & $(3.2-) 3.7-4.3(-4.7)$ & 3.9 & $2.1-2.9$ & 2.5 \\
\hline HK 7384 & 7.4-9.5 $(-10.1)$ & 8.5 & 3-3.4 $(-3.6)$ & 3.2 & $2.1-3.3$ & 2.7 \\
\hline \multicolumn{7}{|l|}{ P. tsugae } \\
\hline Cain, UT 15220 & 6-7.5(-8) & 6.9 & $(3.1) 3.3-4(-4.1)$ & 3.7 & $1.5-2.6$ & 1.9 \\
\hline PK 4494a & $(6.8-) 7-8.8(-9.1)$ & 7.8 & 4-4.7(-4.9) & 4.4 & $1.6-2.2$ & 1.8 \\
\hline \multicolumn{7}{|l|}{ P. alnicola } \\
\hline PK 5956 (spores) & $(3.1-) 3.3-4.1$ & 3.7 & $2.6-3.3(-3.5)$ & 2.9 & $1.1-1.4$ & 1.2 \\
\hline PK 5956 (conidia) & $4.6-) 5-6.8(-7)$ & 5.7 & $3.6-4.6(-5)$ & 4.1 & $1.2-1.7$ & 1.4 \\
\hline \multicolumn{7}{|l|}{ T. araneosa } \\
\hline $\begin{array}{l}\text { PK 4454a (incl. } \\
\text { spines) }\end{array}$ & $4.9-5.2(-6)$ & 5.1 & $3.9-4.2(-4.9)$ & 4.1 & $1.1-1.3$ & 1.2 \\
\hline $\begin{array}{l}\text { PK 4454a (excl. } \\
\text { spines) }\end{array}$ & $(3.7-) 4-5(-5.2)$ & 4.4 & $(2.7-) 3-3.7$ & 3.1 & $1.2-1.6$ & 1.4 \\
\hline
\end{tabular}

\section{References}

Ahti, T., Hämet-Ahti., L. \& Jalas, J. 1968: Vegetation zones and their sections in northwestern Europe. Ann. Bot. Fennici 5: 169-211.

Bourdot, H. \& Galzin, A. 1928: Hyménomycètes de France. Hetétobasidiés-Homobasidiés gymnocarpes. - 761 pp. Soc. Myc. France, Marcel Bry. Sceaux.

Burt, E.A. 1926: The Thelephoraceae of North America XV. - Ann. Missouri Bot. Garden 13: 173-354.

Eriksson, J. \& Hjortstam, K. 1969: Four new taxa of Hyphodontia (Basidiomycetes). - Svensk Bot. Tidskr. 63: $217-232$.

Eriksson, J. \& Ryvarden, L. 1975: The Corticiaceae of North Europe 3: 287-546. - Fungiflora, Oslo.

Eriksson, J. \& Ryvarden, L. 1976: The Corticiaceae of North Europe 4: 547-886. - Fungiflora, Oslo.

Gärdenfors, U. (ed.) 2010: Rödlistade arter i Sverige 2010 - The 2010 Red List of Swedish Species. - 590 pp. ArtDatabanken, SLU, Uppsala.

Ghobad-Nejhad, M., Hallenberg, N., Parmasto, E. \& Kotiranta, H. 2009: A first annotated checklist of corticioid and polypore basidiomycetes of the Caucasus region. - Mycol. Balcanica 6: 123-168.
Ginns, J. \& Lefebvre, M.N.L. 1993: Lignicolous corticioid fungi (Basidiomycota) of North America. Systematics, distribution, and ecology. - Mycol. Memoir 19: 1-247.

Hallenberg, N. 1978: Wood-fungi (Corticiaceae, Coniophoraceae, Lachnocladiaceae, Thelephoraceae) in N. Iran 1. - Iran J. Plant Path. 14: 38-87.

Halme, P. 2010: Lisäyksiä Pirkanmaan tunnettuun sienilajistoon. - Sienilehti 62: 50-54. [In Finnish].

Hansen, L. \& Knudsen, H. 1997 (eds.): Nordic macromycetes 3. Heterobasidioid, aphyllophoroid and gastromycetoid basidiomycetes. - 444 pp. Nordsvamp, Copenhagen.

Heikinheimo, O. \& Raatikainen, M. 1981: Grid references and names of localities in the recording of biological finds in Finland. - Notulae Entomologicae 61: 133-154. [In Finnish with English summary].

Hjortstam, K., Larsson, K-H. \& Ryvarden, L. 1988: The Corticiaceae of North Europe 8. 1449-1631.

Hjortstam, K. \& Ryvarden, L. 2009: A checklist of names in Hyphodontia sensu stricto - sensu lato and Schizopora with new combinations in Lagarobasidium, Lyomyces, Kneiffiella, Schizopora, and Xylodon. - Synopsis Fungorum 26: 33-55. 
Jülich, W. 1984: Die Nichtblätterpilze, Gallertpilze und Bauchpilze (Aphyllophorales, Heterobasidiomycetes, Gasteromycetes). - In: Gams, H. (ed.), Kleine Kryptogamenflora 2b(1), Basidiomyceten 1. 626 pp. Gustay Fischer Verlag, Stuttgart \& New York.

Jülich, W. \& Stalpers, J.A. 1980: The resupinate non-poroid Aphyllophorales of the temperate northern hemisphere. - Verh. Konink. Ned. Akad. Wetensch., Afd. Natuurkunde, Tweede Reeks 74: 1-335.

Kotiranta, H. \& Saarenoksa, R. 1993: Rare Finnish Aphyllophorales (Basidiomycetes) plus two new combinations in Efibula. - Ann. Bot. Fennici 30: 211-249.

Kotiranta, H., Saarenoksa, R. \& Kytövuori, I. 2009: Aphyllophoroid fungi of Finland. A check-list with ecology, distribution, and threat categories. - Norrlinia 19: 1-223.

Krieglsteiner, G.J. 1991: Verbreitungsatlas der Grosspilze Deutschlands (West). Band 1: Ständerpilze, Teil A: Nichtblätterpilze. - 416 pp. Verlag Eugen Ulmer, Stuttgart.

Kunttu, P., Kosonen, T., Kulju, M. \& Kotiranta, H. 2009: Phlebia cremeoalutacea new to Finland and new records of rare corticioid fungi (Basidiomycota). Karstenia 49: 69-71.

Langer, E. 1994: Die Gattung Hyphodontia John Eriksson. - Bibl. Mycologica 154: 1-298.

Larsson, K-H. 1995: Taxonomy of Trechispora farinacea and proposed synonyms I. Species with a grandinioid or hydnoid hymenophore. - Symb. Bot. Upsal. 33: 101-118.

Larsson, K-H. 2007: Molecular phylogeny of Hyphoder$\mathrm{ma}$ and the reinstatement of Peniophorella. - Mycol. Research 111: 186-195.
Lindgren, L., von Numers, M. \& Hæggström, C.-A. 2001: Saariston arvokkaat maabiotoopit. - In: von Numers, M. (ed.): Saaristoympäristöt - nykytila, ongelmat ja mahdollisuudet: 147-160. Nordiska Ministerrådets Skärgårdssamarbete, Turku. [In Finnish]

Parmasto, E. 1965: Corticiaceae U.R.S.S. 1. Descriptiones taxorum novarum. Combinationes novae. Eesti Tead. Akad. Toim. 14: 220-233.

Rassi, P., Alanen, A., Kanerva, T. \& Mannerkoski, I. (eds.) 2001: The 2000 Red List of Finnish Species - 432 pp. Ministry of the Environment \& Finnish Environment Institute, Helsinki. [In Finnish with English summary]

Renvall, P. 1995: Community structure and dynamics of wood-rotting Basidiomycetes on decomposing conifer trunks in northern Finland. - Karstenia 35: 1-51.

Ryvarden, L., Stokland, J. \& Larsson, K-H. 2003: A critical checklist of corticioid and poroid fungi of Norway. - Synopsis Fungorum 17: 1-109.

Torkelsen, A-E. 1997: Urediniomycetes, Platygloeales Moore, Cystobasidiaceae Gäumann. - In: Hansen, L. \& Knudsen, H. (eds.), Nordic macromycetes 3. Heterobasidioid, aphyllophoroid and gastromycetoid basidiomycetes: 75-79. Nordsvamp, Copenhagen.

Vauras, J. 2000: Macrofungi of the Southwestern Archipelago National Park - Metsähallituksen luonnonsuojelujulkaisuja A 112: 1-91. [In Finnish with English summary].

Vesterholt, J. 1997: Hyphodermatales Jülich - In: Hansen, L. \& Knudsen, H. (eds.), Nordic macromycetes 3. Heterobasidioid, aphyllophoroid and gastromycetoid basidiomycetes: 196-205. Nordsvamp, Copenhagen.

de Vries, B.W.L. 1987: Some new corticioid taxa. - Mycotaxon 28: 77-90. 